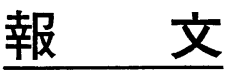

（色材，59[12] 732-740. 1986）

\title{
Oxidation Treatment of Organic Pigments by Low Temperature Plasma
}

\author{
Tatuhiko IharA*, Seisirô Itố**, Masami TANAKA** and Mitsuo KiboKU*
}

\begin{abstract}
Surface modification of organic pigments through polarization was carried out by applying the surface treating method of low temperature plasma to several organic pigments which have poor miscibility with or dispersibility in polar vehicles such as water.

The $\mathrm{pH}$ value of the sample as an indicator of the treatment effect lowered with the increase of the treating time and/or the increase of the oxygen flow rate. Comparing the degree of surface hydrophilic nature by the kind of pigment, the degree increased in order of $\mathrm{CuPc}, \mathrm{DV}$ and $\mathrm{QR}$ under the same treating conditions. From the result of XPS measurements for DV, it was recognized that components assigned to $\mathrm{C}-\mathrm{C}$ and $\mathrm{C}-\mathrm{H}$ were decreased and component assigned to $\mathrm{C}-\mathrm{O}$ or $\mathrm{COO}$ was increased by plasma treatment. The pattern of difference spectra obtained by FT-IR measurement was assigned to that of carboxylic acid. The untreated pigments hardly dispersed in water, while the dispersibility of treated pigments were improved.
\end{abstract}

\section{INTRODUCTION}

Generally, modern organic pigments of high quality, for example, sharpness, tinting strength, transparency, fastness, etc. have poor miscibility and dispersibility in polar vehicles such as water because these organic pigments are non-polar at the surface of their particles. Consequently, in order to overcome this disadvantage, it is necessary to polarize the surface of the particles of organic pigments. The most conventional method is a wet surface treatment procedure using a surface treating agent. In fact, many high quality organic pigments have been treated by this method. In this case, the derivatives corresponding to the organic pigment are conventionally used as the surface treating agent; however, it is difficult to treat only surface layers by this procedure. Thus, the favorable properties inherent in the organic pigment such as good fastness may deteriorate.

Recently, rapid progress has taken place in surface treatment technology with the irradiation of low temperature plasma. The authors have investigated the treatment of carbon black with low temperature oxygen plasma to improve water dispersibility ${ }^{1 \sim 4)}$. The results indicated that the introduction of a polar group, such as a carboxyl or hydroxyl group, onto the surface layer provides the necessary polarity without deteriorating the original properties of the pigment.

The paper describes the surface modification of pigments through polarization by applying the surface treating method of low temperature plasma to several organic pigments.

\section{EXPERIMENTAL}

\subsection{Materials and plasma equipment}

Dioxazine Violet (C.I. Pigment Violet 23 ; abbreviated DV) and $\gamma$ type Quinacridone Red (C.I. Pigment Violet 19 ; abbreviatedQR) from DuPont and $\beta$ type $\mathrm{Cu}$ Phthalocyanine Blue(C. I. Pigment Blue

昭和 61.6.16 受理

* Faculty of Engineering, Kinki University, Hiro, Kure, 737-01, Japan

** Faculty of Science and Engineering, Kinki University, Kowakae, Higashiosaka, 577, Japan 
15 ; abbreviated $\mathrm{CuPc}$ ) from Sumitomo Chemical Industrial Co. were used as the organic pigment. All pigments were the surface-untreated products. The chemical structures of these pigments are shown in Fig. 1.

The plasma treating equipment, as described in the previous report ${ }^{11}$, was used and the inductive loading type with a coil was applied to the high frequency loading system.

\subsection{Treating method}

The low temperature plasma treating method was carried out in almost the same way as for carbon black mentioned in the previous report $t^{11}$. The treating procedure is as follows: $10 \mathrm{~g}$ of the organic pigment is put into the pyrex reactor which is evacuated for $1 \mathrm{~h}$ under the pressure of 0.5 Torr. Oxygen, supplied from a cylinder, is passed through the reactor while evacuating. The stirrer is revolved around and on its axis while high-frequency is applied under the specified pressure. The conditions of plasma are maintained while treating the sample. The number of revolutions is constantly $10 \mathrm{rpm}$ and the number of revolutions on its axis is 6 per a revolution.

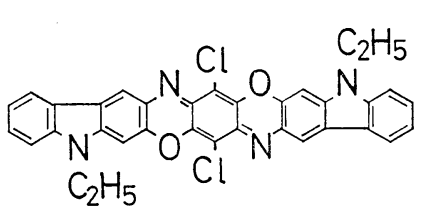

Dioxazine Violet<smiles>O=c1c2ccccc2[nH]c2cc3c(=O)c4ccccc4[nH]c3cc12</smiles>

$\boldsymbol{\gamma}$ type Quinacridone Red

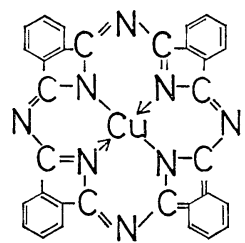

$\beta$ type Cu Phthalocyanine Blue

Fig. 1. Structures of pigments

\section{3 Measurements}

In order to confirm a change of properties as a result of plasma treatment, specific surface area determined by $\mathrm{N}_{2}$ adsorption $\left(\mathrm{S}_{\mathrm{N} 2}\right)$, specific surface area determined by water vapor adsorption $\left(\mathrm{S}_{\mathrm{H}_{2} \mathrm{O}}\right.$ ), $\mathrm{pH}$, FT-IR spectrum, XPS and FDMS (field desorption mass spectrum) were determined and the dispersion in water was observed. Separation of degradation products formed on the pigment surface by this plasma oxidation treatment and its IR spectrum measurements were also carried out. In these measurements, $\mathrm{S}_{\mathrm{N}_{2}}{ }^{2)}, \mathrm{pH}^{3)}$, and the observation of dispersion in water ${ }^{3)}$ were determined by the same procedures as the previous report. The other measurements and experiments were carried out in the following manner :

2. 3. $1 \quad \mathrm{~S}_{\mathrm{H}_{2} \mathrm{O}}$

$\mathrm{S}_{\mathrm{H}_{2} \mathrm{O}}$ was determined by applying the BET equation to the water vapor adsorption isotherms measured by a quartz spring balance method using a water vapor adsorption apparatus Model P-850 manufactured by Shibata Scientific Technology Ltd.. In the calculation, the value for the cross-section of the water molecule was supposed to be $10.8 \mathrm{~A}^{2}$.

2.3. 2 FT-IR spectrum

FT-IR spectrum was recorded on a Digilab Model FTS-15E spectrophotometer. The sample was measured by the ATR method and the numbers of integration were set to 400 times.

2.3. 3 XPS

XPS measurement and its wave-form analysis were carried out by Shimadzu-DuPont Model ESCA 650 B spectrometer and Model ESCAPAC 660 respectively.

\section{3.4 FDMS}

FDMS was recorded using a Hitachi Model M-80 (A) mass spectrometer.

\subsection{Degradation products}

Separation of degradation products from pigments was carried out by the following method: 100 $\mathrm{m} l$ of $0.5 \mathrm{~mol} \cdot \mathrm{dm}^{-3} \mathrm{NaOH}$ solution was added to $10 \mathrm{~g}$ of pigment. After stirring for $96 \mathrm{~h}$ at room temperature using magnetic stirrer, the suspension was filtered off using filter paper (No. 5 C). Then, the pigment particles in the filtrate were filtered off completely by ultrafiltration, and filtrate containing degradation products was dried in vacuo. For the degradation products, measurement of IR spectra was carried out by the $\mathrm{KBr}$ tablet method using IR spectrophotometer IR-810 manufactured by Nihon Bunko. 
Table 1. Plasma treating conditions and specific surface areas $\left(\mathrm{S}_{\mathrm{N}_{2}}\right.$ : determined by $\mathrm{N}_{2}$ adsorption, $\mathrm{S}_{\mathrm{H}_{2} \mathrm{O}}$ : determined by water vapor adsorption) and $\mathrm{pH}$

\begin{tabular}{|c|c|c|c|c|c|}
\hline \multirow{2}{*}{ Pigments } & \multicolumn{2}{|c|}{ Treating conditions* } & \multirow{2}{*}{$\begin{array}{c}\mathrm{S}_{\mathrm{N}_{2}} \\
\left(\mathrm{~m}^{2} / \mathrm{g}\right)\end{array}$} & \multirow[b]{2}{*}{$\begin{array}{c}\mathrm{S}_{\mathrm{H}_{2} \mathrm{O}} \\
\left(\mathrm{m}^{2} / \mathrm{g}\right)\end{array}$} & \multirow[b]{2}{*}{$\mathrm{pH}$} \\
\hline & $\begin{array}{l}\mathrm{O}_{2} \text { flow rate } \\
(\mathrm{m} l / \mathrm{min})\end{array}$ & $\begin{array}{l}\text { Treating time } \\
(\mathrm{h})\end{array}$ & & & \\
\hline \multirow{10}{*}{ DV } & \multicolumn{2}{|c|}{ Non-treated } & 98. 49 & 4. 96 & 5. 45 \\
\hline & 10 & 1 & - & - & 5. 08 \\
\hline & 10 & 3 & - & - & 4. 01 \\
\hline & 10 & 5 & - & 一 & 3. 67 \\
\hline & 30 & 1 & - & - & 4.62 \\
\hline & 30 & 3 & - & - & 3. 42 \\
\hline & 30 & 5 & 一 & - & 3.28 \\
\hline & 40 & 1 & 91.81 & 8.35 & 4.55 \\
\hline & 40 & 3 & 91.45 & 13. 37 & 2.81 \\
\hline & 40 & 5 & 89.26 & 18. 75 & 2.60 \\
\hline \multirow{10}{*}{ QR } & \multicolumn{2}{|c|}{ Non-treated } & 24.68 & 1. 64 & 8.84 \\
\hline & 10 & 1 & - & - & 8. 27 \\
\hline & 10 & 3 & - & - & 6. 88 \\
\hline & 10 & 5 & - & - & 6.20 \\
\hline & 30 & 1 & - & - & 5.82 \\
\hline & 30 & 3 & - & - & 4. 51 \\
\hline & 30 & 5 & - & - & 3. 75 \\
\hline & 40 & 1 & 22.37 & 4. 36 & 4. 33 \\
\hline & 40 & 3 & 22.51 & 6.98 & 3. 80 \\
\hline & 40 & 5 & 22.36 & 7.99 & 3. 32 \\
\hline \multirow{10}{*}{$\mathrm{CuPc}$} & \multicolumn{2}{|c|}{ Non-treated } & 54.05 & 3. 41 & 6. 78 \\
\hline & 10 & 1 & - & - & 5. 48 \\
\hline & 10 & 3 & - & - & 4. 91 \\
\hline & 10 & 5 & - & - & 4. 76 \\
\hline & 30 & 1 & 一 & - & 4. 39 \\
\hline & 30 & 3 & - & - & 4.26 \\
\hline & 30 & 5 & - & - & 4. 05 \\
\hline & 40 & 1 & 53.68 & 5. 21 & 4. 34 \\
\hline & 40 & 3 & 52.12 & 7.50 & 4. 05 \\
\hline & 40 & 5 & 54.33 & 8. 16 & 3. 88 \\
\hline
\end{tabular}

* Radio frequency power : $30 \mathrm{~W}$

\section{RESULTS and DISCUSSION}

Plasma treating conditions and $\mathrm{pH}, \mathrm{S}_{\mathrm{H}_{2} \mathrm{O}}$ and $\mathrm{S}_{\mathrm{N}_{2}}$ for nontreated samples and plasma treated samples are shown in Table 1.

The ratio of $\mathrm{S}_{\mathrm{H}_{2} \mathrm{O}}$ and $\mathrm{S}_{\mathrm{N}_{2}}$ is defined as a measure which represents the hydrophilic nature of the solid surface by Zettlemoyer ${ }^{5)}$. In this paper, this definition was applied and the ratios of $\mathrm{S}_{\mathrm{H}_{2} \mathrm{O}}$ and $\mathrm{S}_{\mathrm{N}_{2}}$ were shown in Fig. 2.

Degree of surface hydrophilic nature $(\%)=\frac{\mathrm{S}_{\mathrm{H}_{2} \mathrm{O}}}{\mathrm{S}_{\mathrm{N}_{2}}} \times 100$

Comparing the $\mathrm{pH}$ values of the samples as an indicator of the treatment effect according to the treating conditions, the $\mathrm{pH}$ becomes lower as the treating time is increased. Under constant conditions, the $\mathrm{pH}$ value becomes lower as the oxygen flow rate increases as in the case of carbon black ${ }^{4}$. 


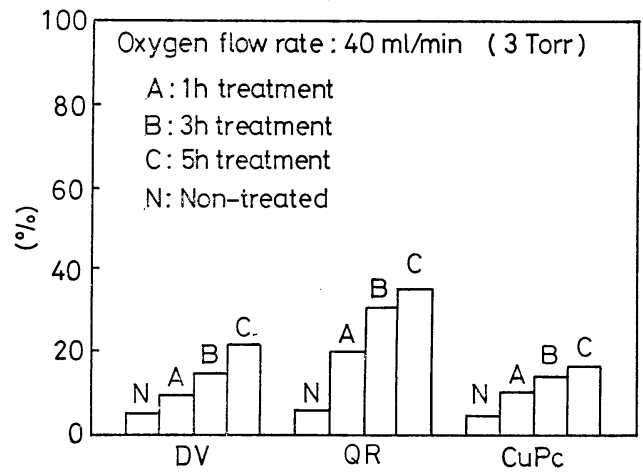

Fig. 2. Changes of degree of surface hydrophilic nature $(\%)$ by plasma treatment

The pressure inside the plasma reactor during treatment at an oxygen flow rate of $10 \mathrm{ml} / \mathrm{min}$, $30 \mathrm{~m} l / \mathrm{min}$ and $40 \mathrm{~m} l / \mathrm{min}$ corresponds to approximately 0.5 Torr, 2.0 Torr and 3.0 Torr, respectively.

$\mathrm{S}_{\mathrm{N}_{2}}$ of the sample shown in Table 1 shows that plasma treatment tends to decrease the specific surface area, $\mathrm{S}_{\mathrm{N}_{2}}$. However, it is not a large change and there is no precise relationship between treating conditions and the changes in $\mathrm{S}_{\mathrm{N}_{2}}$ as in the case of carbon black.

The hydrophilic nature of the surface, shown in Fig.2, for the samples treated by the most effective conditions at an oxygen flow rate of $40 \mathrm{~m} l / \mathrm{min}$, indicates that the hydrophilic nature increases with increasing time. But the increasing degree of that in $\mathrm{QR}$ and $\mathrm{CuPc}$ decrease with increasing time. These pigments have relatively small $\mathrm{S}_{\mathrm{N}_{2}}$.

In the case of DV which has a relatively large $\mathrm{S}_{\mathrm{N}_{2}}$, it directly increases with increasing time.

Comparing the degree of surface hydrophilic nature by the kind of pigment, the degree increases in order of $\mathrm{CuPc}, \mathrm{DV}$ and $\mathrm{QR}$ under the same treating time of $5 \mathrm{~h}$.

The different specific surface area $\left(\mathrm{S}_{\mathrm{N}_{2}}\right)$ of the pigments accounts for the difference in the rate of surface modification.

Considering that sample degradation by combustion occurs simultaneously with the oxidation of the sample surface ${ }^{3)}$ and the sample degradation occurs preferentially from the site where the oxygen containing surface functional groups are formed, the pigment stability in the plasma seems to be influenced by the chemical structure of the pigment. It is thought, therefore, that the sample degradation reaction proceeds faster than the sample oxidation reaction for pigments which are unstable in the plasma. In such a case, very little oxidation of the sample's surface occurs as the result. This is also considered to be a reason why the hydrophilic nature differs with the kind of pigment.

In order to evaluate the stability of the pigments in the plasma, weight change of the sample was determined by plasma irradiation using oxygen and argon plasma without stirring. This determination was also used for carbon black (abbreviated $\mathrm{CB}$ ) as a comparison. These measurements were carried out ten times for respective pigments and the averages are shown in Fig. 3.

The weight loss increased in order of $\mathrm{CuPc}<\mathrm{QR} \leqq \mathrm{DV}<\mathrm{CB}$ under both plasma treatments. The results indicate that these organic pigments are relatively stable in comparison with $\mathrm{CB}$, and $\mathrm{CuPc}$ is the most resistant to decomposition. The weight loss which occurs with argon plasma irradiation suggests that the reaction on the surface of the solid in the plasma is caused by the spattering of ions accelerated in an ion sheath in the plasma. This corresponds to our proposal mentioned previously). Weight loss was greater at 3 Torr than at 1 Torr showing that the spattering efficiency at high pressure is greater than that at low pressure. This reveals that the relationship of spattering efficiency to treating pressure, which was mentioned previously ${ }^{4)}$, was reverse. 
The amount of activated sites produced on the surface of a pigment such as $\mathrm{CuPc}$, which is highly stable in the plasma, is small; therefore, very little surface oxidation and decomposition of the oxidized site occur. In a pigment which is relatively stable in plasma like $\mathrm{QR}$ or $\mathrm{DV}$, the activated sites are easily produced on its surface, and the oxidation of these sites occurs relatively easily. Considering the specific surface area $\left(\mathrm{S}_{\mathrm{N}_{2}}\right)$ of these two pigments, the modification effect appeared in QR because it is relatively stable in plasma and has a small specific surface area $\left(\mathrm{S}_{\mathrm{N}_{2}}\right)$; therefore, the hydrophilic nature of the surface, shown in Fig. 2, no longer increased when the treating time is longer than $3 \mathrm{~h}$. DV is also relatively stable in plasma but has a large $\mathrm{S}_{\mathrm{N}_{2}}$; hence, the hydrophilic nature of the surface directly increased with time, but was overall lower than that of QR.

The pigment's stability in plasma is due to several characteristics: the chemical structure of the pigment, the kind of surface functional groups, crystallinity and particle diameter, etc. .

The non-treated pigments dispersed little in water, while the dispersibility of treated samples are improved. The dispersibility in water is closely related to the $\mathrm{pH}$, so that the former is increased as the latter is lowered in the same manner as for carbon black ${ }^{4}$. The dispersibility of $\mathrm{CuPc}$ is, therefore, slightly lower than those of DV and QR.

Figures 4 through 6 show the measurements from FT-IR spectra and the difference spectra of non-treated and treated samples, respectively, of $\mathrm{DV}, \mathrm{QR}$, and $\mathrm{CuPc}$.

The difference spectra of these treated samples give newly developed absorption bands near 3,000 $\mathrm{cm}^{-1}$ to $3,400 \mathrm{~cm}^{-1}$ and $1,710 \mathrm{~cm}^{-1}$ which are attributed to hydroxyl and carboxyl groups. It was revealed that hydroxyl and carboxyl groups were introduced on the surface of the sample by this plasma treatment. The absorption bands become stronger with an increase of treating pressure and time in the same manner as that of the $\mathrm{pH}$ shown in Table 1. The strength for $\mathrm{CuPc}$, however, was weaker than the others in any treating conditions.

The spectra of the treated samples of $\mathrm{QR}$ and $\mathrm{CuPc}$ give another newly developed absorption band near $1,390 \mathrm{~cm}^{-1}$ which is probably based on $\mathrm{N}$-oxide groups.

As shown in Fig. 1, QR and $\mathrm{CuPc}$ has respectively two imino groups and four symmetric iso-indol rings connected with the nitrogen atom in a molecule. The production of $\mathrm{N}$-oxide groups indicates the oxidation of the imino group by the oxygen plasma in the case of $\mathrm{QR}$. In the case of $\mathrm{CuPc}$, the bonds of nitrogen with four iso-indol rings are broken resulting in ring cleavage. These parts are then oxidized to $\mathrm{N}$-oxide groups.

It is conceivable, therefore, that because the carboxyl group is produced in a smaller quantity in

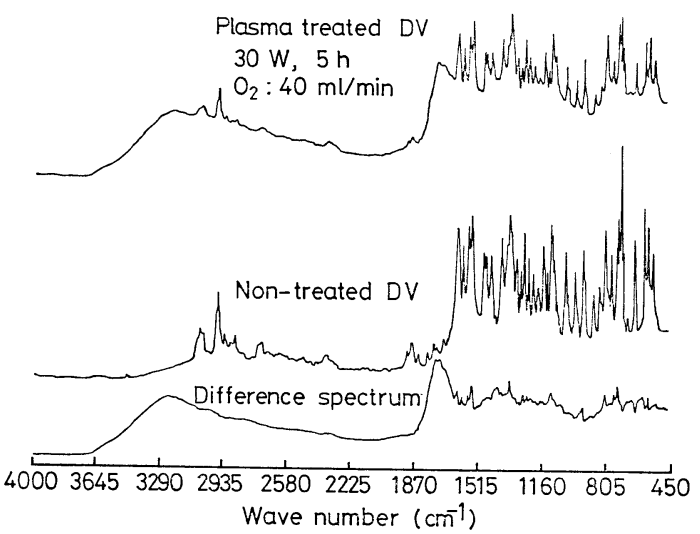

Fig. 4. FF-IR spectra of DV

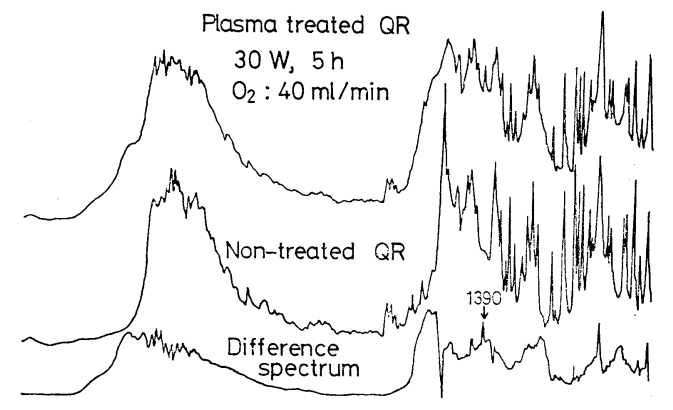

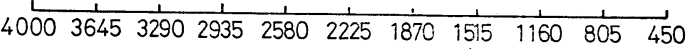
Wave number $\left(\mathrm{cm}^{-1}\right)$

Fig. 5. FI-IR spectra of $Q R$

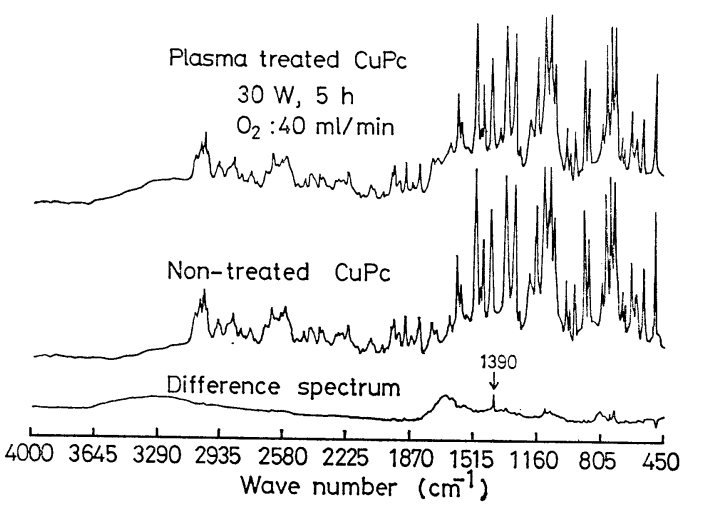

Fig. 6. FT-IR spectra of $\mathrm{CuPc}$ 
Table 2. Abundance ratio of the atoms obtained from the wide scanning determination by XPS

\begin{tabular}{ll|c|c|c|c|c}
\hline \multirow{2}{*}{ Peakes } & \multirow{2}{*}{ R. I. } & \multicolumn{2}{|c|}{ Non-treated } & \multicolumn{2}{|c|}{ Plasma treated } & \multirow{2}{*}{$\begin{array}{c}\text { Theoretical } \\
\text { ratio }\end{array}$} \\
\cline { 3 - 6 } & $\begin{array}{c}\text { Peak height } \\
(\mathrm{mm})\end{array}$ & $\begin{array}{c}\text { Abundance ratio } \\
\text { of the atom }\end{array}$ & $\begin{array}{c}\text { Peak height } \\
\text { (mm) }\end{array}$ & $\begin{array}{c}\text { Abundance ratio } \\
\text { of the atom }\end{array}$ & 34 \\
\hline $\mathrm{C}_{1 \mathrm{~s}}$ & 0.25 & 43.5 & 28.6 & 39.5 & 27 & 4 \\
$\mathrm{~N}_{1 \mathrm{~s}}$ & 0.4 & 9.5 & 4 & 9.0 & 4 & 2 \\
$\mathrm{O}_{1 \mathrm{~s}}$ & 0.6 & 11.2 & 3.1 & 17.5 & 5 & 2.5 \\
$\mathrm{Cl}_{2 \mathrm{p}}$ & 0.54 & 7.0 & 2.2 & 8.0 & 2.5 & 2 \\
\hline
\end{tabular}

* : Relative intensity of the element ${ }^{6)}$

$\mathrm{CuPc}$ than in $\mathrm{DV}$ and $\mathrm{QR}$, the decreasing $\mathrm{pH}$ rate of $\mathrm{CuPc}$ is lower and dispersibility in water is not noticeably improved. Instead of a carboxyl group, the $\mathrm{N}$-oxide group is mainly produced.

Consequently, it is estimated that water dispersibility is mainly caused by the formation of carboxyl groups.

The results of XPS wide scanning determination of non-treated and treated DV by plasma are shown in Fig. 7. Only the elements of C, N, $\mathrm{Cl}$ are detected in these samples. Comparing the peak strength before and after plasma treatment, the strength of the $\mathrm{O}_{1 \mathrm{~s}}$ spectrum raises while that of the $C_{1 s}$ spectrum lowers, and those of the other spectra change very little.

The peak heights obtained from the wide scanning determination shown in Fig. 7 are compared in Table 2 along with the abundance ratio of the atoms based on the relative strength of the element ${ }^{6)}$. Table 2 reveals that these values relatively coincide with the theoretical ratios, and $\mathrm{O}$ increases while $\mathrm{C}$ decreases during plasma treatment.

The peaks formed from the XPS narrow scanning determination of $\mathrm{C}, \mathrm{N}$ and $\mathrm{O}$ in $\mathrm{DV}$ were investigated in detail by wave-form analysis. In order to make the analysis, a component peak is regarded as a Gauss distribution curve with the actual form of the peak represented by three to four components. The results are shown in Fig. 8 through 10. The position of each component (bond energy) is calibrated by fixing the minimum bond energy of the main component in the $C_{1 s}$ spectrum of each sample at $285 \mathrm{eV}$.

The results of the wave-form analysis of the non-treated sample are not exactly equivalent to the structural formula (Fig. 1). For instance, the number of two types of $\mathrm{N}$-atoms are equal in the structural formula, but the number of the two types of $\mathrm{N}$-atoms in Fig. 9 are different from each other (Component-1 is few and it is not clear that this peak is significant or not). This difference may exist because the existing state of an

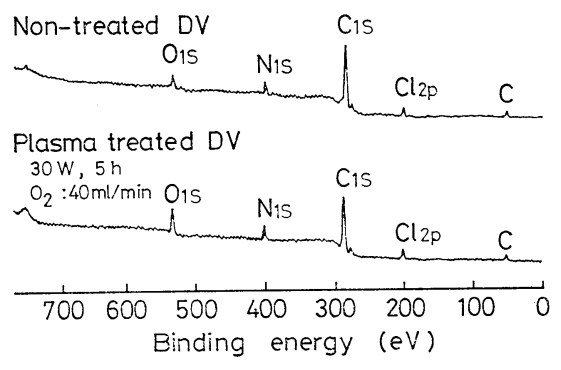

Fig. 7. XPS wide scanning spectra of DV

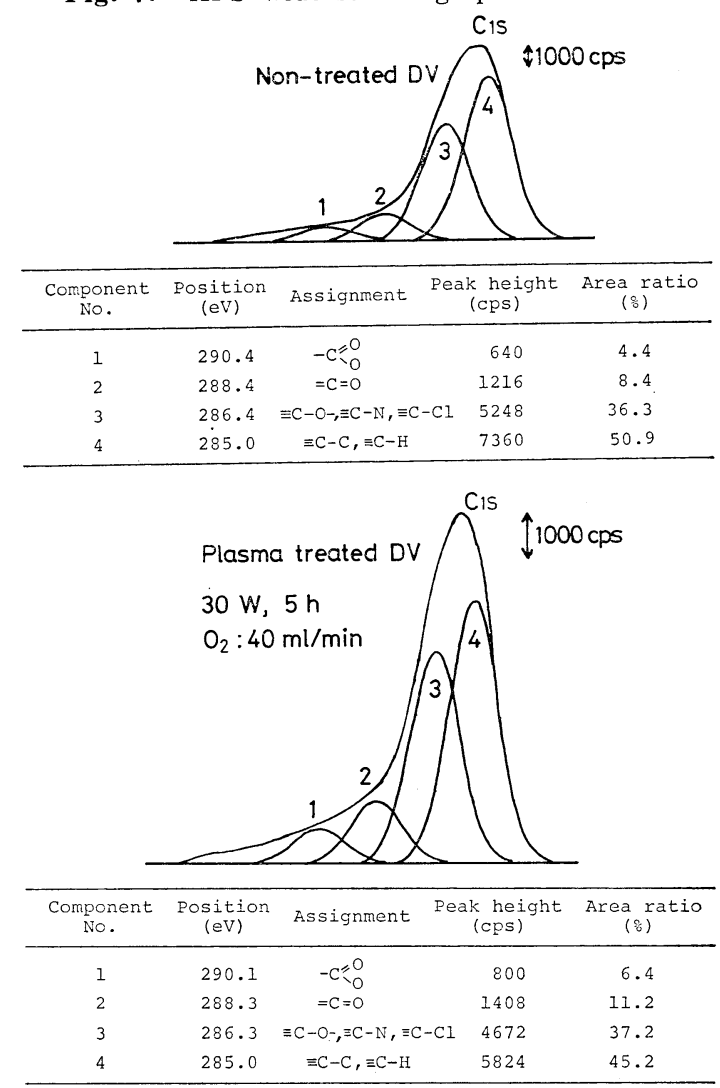

Fig. 8. Wave form analysis of $C_{1 s}$ spectra for treated and untreated DV and their estimated assignment 


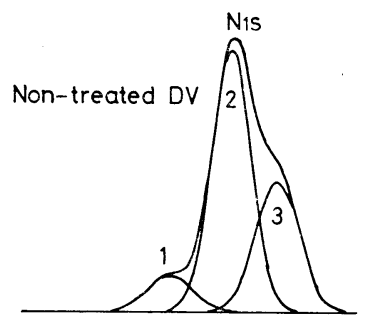

\begin{tabular}{|c|c|c|c|c|}
\hline $\begin{array}{l}\text { Component } \\
\text { No. }\end{array}$ & $\begin{array}{c}\text { Position } \\
\text { (ev) }\end{array}$ & Assignment & $\begin{array}{l}\text { Peak height } \\
\text { (cps) }\end{array}$ & $\begin{array}{c}\text { Area ratio } \\
\left(\frac{\delta}{8}\right)\end{array}$ \\
\hline 1 & 402.7 & Shake up or $\mathrm{N}-\mathrm{O}$ & 208 & 9.1 \\
\hline 2 & 400.5 & $y_{0}^{N} y$ & 1512 & 58.9 \\
\hline 3 & 398.9 & $\begin{array}{l}C_{C}>N-C \\
C^{2}\end{array}$ & 752 & 32.0 \\
\hline
\end{tabular}

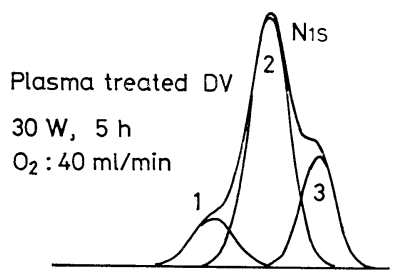

\begin{tabular}{ccccc}
\hline $\begin{array}{c}\text { Component } \\
\text { No. }\end{array}$ & $\begin{array}{c}\text { Position } \\
(\mathrm{eV})\end{array}$ & Assignment & $\begin{array}{c}\text { Peak height } \\
(\mathrm{cps})\end{array}$ & $\begin{array}{c}\text { Area ratio } \\
(\mathrm{8})\end{array}$ \\
\hline 1 & 402.7 & Shake up or N-O & 280 & 13.0 \\
2 & 400.5 & $\mathrm{C}^{\mathrm{N}} \mathrm{O}$ & 1440 & 63.0 \\
3 & 398.9 & $\begin{array}{l}\mathrm{C}^{\prime} \mathrm{N}-\mathrm{C} \\
\mathrm{C}\end{array}$ & 648 & 24.0 \\
\hline
\end{tabular}

Fig. 9. Wave form analysis of $\mathrm{N}_{1 \mathrm{~s}}$ spectra for treated and untreated DV and their estimated assignment
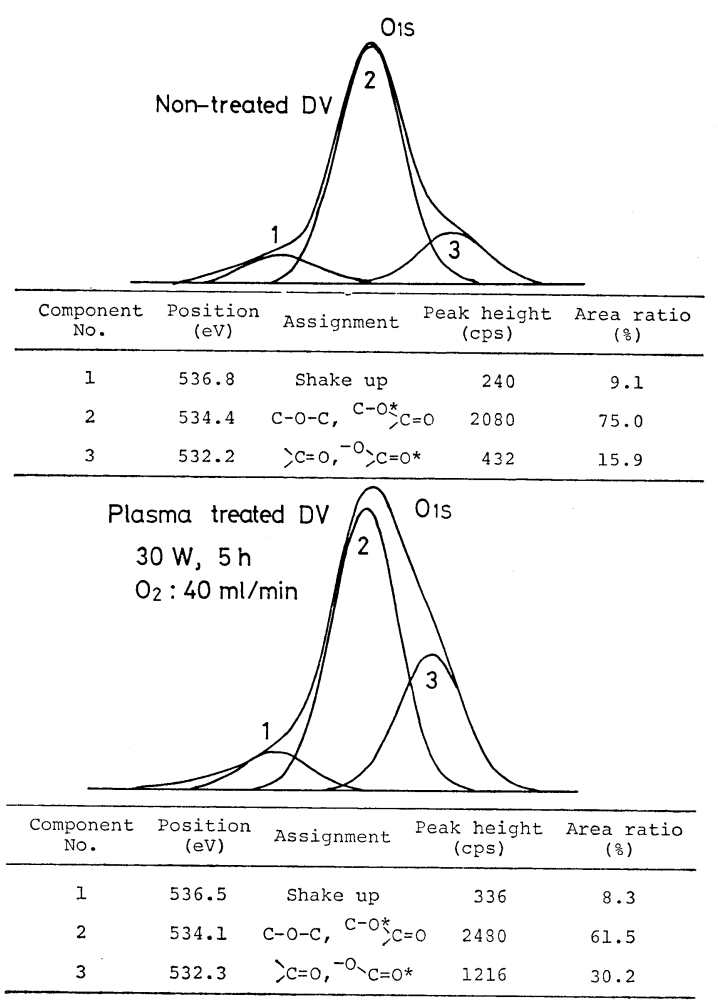

Fig. 10. Wave form analysis of $\mathrm{O}_{1 \mathrm{~s}}$ spectra for treated and untreated DV and their estimated assignment

$\mathrm{N}$-atom on the surface of a particle is different from that in the bulk.

The bond energy obtained by the wave-form analysis and the estimated assignment of each component are shown in Fig. 8 through 10.

The actual peak of $\mathrm{C}_{1 \mathrm{~s}}$ can be approximated by four components though some disagreements remain at higher bond energies. This can be explained by the $\left(\pi \rightarrow \pi^{*}\right)$ shake up process of the benzene ring. The components assigned to $\mathrm{C}-\mathrm{C}$ or $\mathrm{C}-\mathrm{H}$ are decreased by the plasma treatment. It is probably because part of $\mathrm{C}_{2} \mathrm{H}_{5}$ is eliminated or oxidized.

The actual peak of $\mathrm{N}_{1 \mathrm{~s}}$ can be represented with three components, but it is not clear whether the peak of Component-1 is significant. Since the component is slightly increased by plasma treatment, it may be assigned as $\mathrm{N}$ bonded with $\mathrm{O}$. The elimination of part of the $\mathrm{C}_{2} \mathrm{H}_{5}$ group in $\mathrm{C}_{1 \mathrm{~s}}$ corresponds to the decrease of component-3 during plasma treatment.

Although only one type of $\mathrm{O}_{1 \mathrm{~s}}$ exists in the structural formula, no less than two components (Components -2 and -3 ) exist as $\mathrm{O}_{1 \mathrm{~s}}$. Component-3 is considered to be $\mathrm{C}=\mathrm{O}$ or $\mathrm{COO}$. This coincides with the result of $\mathrm{C}_{1 \mathrm{~s}}$. It is revealed that $\mathrm{C}=\mathrm{O}$ or $\mathrm{COO}$ is greatly increased by plasma treatment. Considering the results of the FT-IR spectra, the increasing of carboxyl and hydroxyl groups by plasma treatment is conceivable.

Fig. 11 shows the IR spectra of the degradation products separated from plasma treated DV by the method mentioned in 2.3.5.

In spectrum A, the absorption band near $1,720 \mathrm{~cm}^{-1}$ associated with the $\mathrm{C}=\mathrm{O}$ stretching vibration of a free carboxyl group is negligible. The absorption band near $1,400 \mathrm{~cm}^{-1}$ (based on ionized carboxyl) clearly appeared because it was measured when the degradation products were prepared in alkaline conditions as mentioned in 2.3.5 (the absorption band near $1,600 \mathrm{~cm}^{-1}$, based on antisymmetric stretching vibration of $\mathrm{COO}^{-}$, is not clearly observed because of overlapping of the band shown near $1,600 \mathrm{~cm}^{-1}$ 


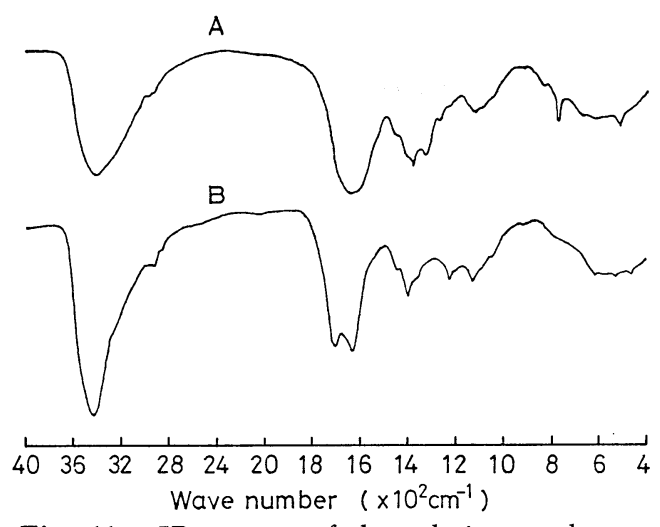

Fig. 11. IR spectra of degradation products separated from plasma treated DV

A : Prepared in alkaline condition

$\mathrm{B}:$ Prepared in acidic condition

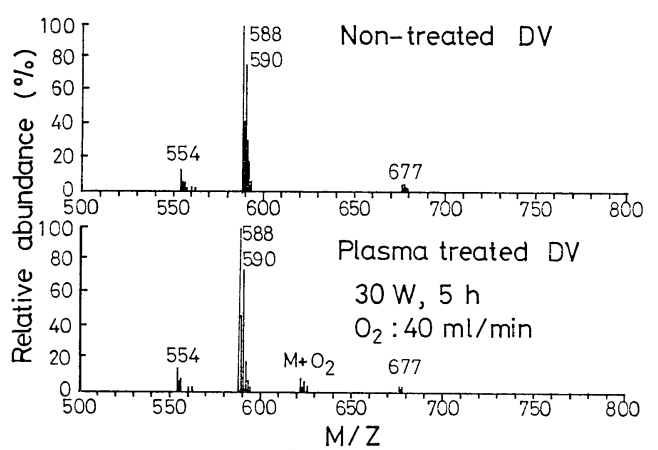

Fig. 12. FDMS spectra of plasma treated and non-treated DV

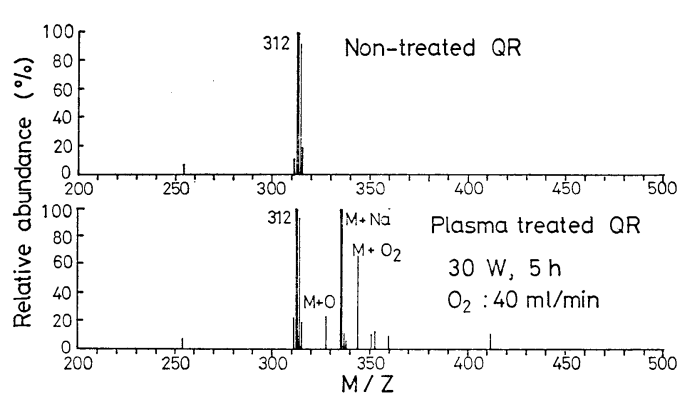

Fig. 13. FDMS spectra of plasma treated and non-treated QR

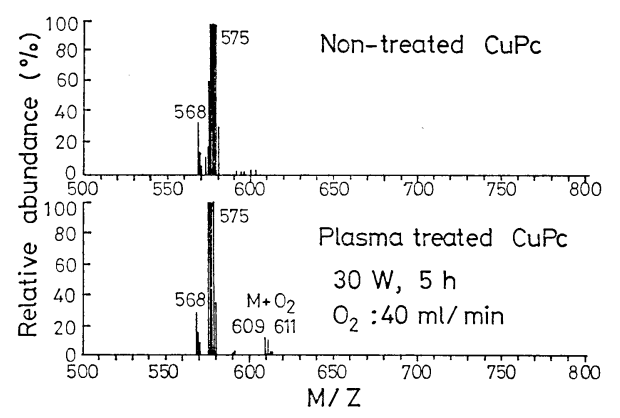

Fig. 14. FDMS spectra of plasma treated and non-treated $\mathrm{CuPc}$

which is based on aromatic rings and adsorbed water).

In spectrum $B$, the absorption band near 1,400 $\mathrm{cm}^{-1}$, based on ionized carboxyl, almost disappeared and a new band near $1,720 \mathrm{~cm}^{-1}$, based on a free carboxyl group, appeared. This occurred because the degradation products were prepared in acidic conditions. This phenomenon was also recognized in $\mathrm{QR}$ and $\mathrm{CuPc}$.

Figures 12 through 14 show the FDMS spectra of plasma treated and non-treated samples of DV, QR and $\mathrm{CuPc}$, respectively.

All plasma treated samples gave new peaks around $\mathrm{M}+\mathrm{O}$ and/or $\mathrm{M}+\mathrm{O}_{2}$.

From these results, it is concluded that the pigment molecules, existing on the skin layer of the pigment particle, are derivated to mono- and/or di-oxidized compounds or N-oxide compounds. The carboxyl group is produced with the formation of degradation products formed on the pigment particle skin layer and exists within degradation products.

\section{References}

1) T. Ihara, S. Itô, T. Kuwahara and M. Kiboku : SHIKIZAI KYOKAISHI, 57, 124 (1984)

2) T. Ihara, S. Itô, T. Kuwahara and M. Kiboku : SHIKIZAI KYOKAISHI, 56, 301 (1983)

3) T. Ihara, S. Itô, T. Kuwahara and M. Kiboku : SHIKIZAI KYOKAISHI, 54, 531 (1981)

4) T. Ihara, S. Itô, T. Kuwahara and M. Kiboku : J. Chem. Soc. Jpn., 1984, 1575

5) A.C. Zettlemoyer: Off. Digest, 29, 1238 (1957)

6) H. Berthou, C. K. J申rgensen : Anal. Chem., 47, 482 (1975) 


\title{
有機顔料の低温プラズマ酸化処理
}

\author{
井原辰彦 ・伊藤征司郎 ${ }^{* *}$ ・田中雅美 ${ }^{* *} \cdot$ 木卜光夫*
}

* 近畿大学工学部工業化学科・点市広町 1000 ( $7737-01)$

** 近畿大学理工学部応用化学科・東大阪市小若江 3-4-1 (于577)

\begin{abstract}
要旨
極性溶媒系ビヒクル中への分散性がよくない有機顔料の表面の極性化を目的として，低温プラズマによる表面 処理を試みた。

処理効果の目安となる試料の $\mathrm{pH}$ は, 酸素流量および処理時間に比例して低くなった。同じ処理条件で処理し た顔料の表面親水度を比較すると，CuPc，DV，QR の順に高い值を示した。DV についてXPS 測定を行った ところ，C-C，C-H に帰属される成分の減少と C-O あるいは $\mathrm{COO}$ に帰属される成分の顕著な增大が確認され た。FT-IR 測定によって得た未処理試料とプラズマ処理試料の差スペクトルは, カルボン酸の吸収パターンを 示した。いずれの顔料もプラズマ処理によって水分散性が改善されることが認められた。
\end{abstract}

\section{お知らせ}

\section{関塗エセミナー「塗料のサイエンス」}

\section{シリーズ第 2 回}

\section{分散に関して}

主 催 関東塗料工業組合

日 時 昭和 62 年 2 月 26 日 (木) $\cdot 27$ 日（金） $9: 30 \sim 16: 50$

場 所 東京塗料会館

講師 職業訓練大学校塗装科教授 工博 吉田豊彦
講 義 第1日：(1) 分散と凝集，（2）好（湿 潤）之分散，（3）顔料表面の性質，（4） 安定化のメカニズム，第 2 日：(5) 分散と 凝集の評価, (6) 分散の速度論

定 員 60 名

受講料（テキスト，昼食費を含む）関東塗料工 業組 合員会社 1 名 25,000 円，員外会社 1 名 30,000 円

申込締切 昭和 62 年 2 月 10 日（但，定員になり次第 締切)

申 込 先 7160 新宿区南元町 5-8 (東京塗料会館) 関東塗料工業組合（Tel.03（341）8137) 